\title{
Practical training as the main component of the process of specialist training in the agricultural sector
}

\author{
T. M. Karchevska \\ Podilskyi State Agrarian and Technical University, Kamianets-Podilskyi, Ukraine \\ Corresponding author. E-mail: ktmkp2015@ gmail.com
}

Paper received 29.10.21; Accepted for publication 15.11.21.

\begin{abstract}
https://doi.org/10.31174/SEND-PP2021-259IX101-04
\end{abstract}
\begin{abstract}
The article highlights the psychological aspects of practical training of higher education students. The key points of this concept are presented in the context of the maximum approximation of practical preparation for produc-tion activites, readiness to constantly improve one's knowledge, update practical skills, and rapidly adapt to changes in both internal and external environment in the future professional carrear.
\end{abstract}

Keywords: practical training, professional activity, production situation, practical skills, agrarian specialists.

Introduction. Practical training as a component of the training process of a specialist in the agricultural sector is specified by a system of tasks of practical training, the main of which are: mastering professional knowledge, skills and abilities, the culture of mental and physical labor; formation of social motives of positive and creative attitude to future professional activity; development of high moral qualities: diligence, responsibility, purposefulness, enterprise, industry, honesty, thrift, practicality, mastery; development of logical thinking and skills of practical analysis.

A brief overview of publications on the topic. The professional activity of any specialist is full of both habitual and unplanned, changing situations that require prompt decision-making, ambiguity in the interpretation of events related to unexpected human behavior. This requires specialists to have deep professional knowledge, skills to discuss and reflect on professional issues; argue their own positions, make decisions and bring them to the attention of partners; choose behavioral strategies that are adequate to the professional communication situation, etc. The mastery of these skills is facilitated by the introduction of modern learning technologies, in particular the technology of situation analysis [1].

The process of practical training of the future specialist in the agricultural sector is quite complex, it is objectively inherent in both patterns and certain contradictions. The main contradiction of this process is between the student's educational activity and the professional activity of the future agrarian specialist [7]. In the traditional educational process there is a three-member technological chain: 1) presentation of information by the teacher; 2) perception, comprehension, summarizing, memorizing information by the student; 3 ) reproduction of the studied information by the student for control and evaluation by the teacher [6]. In a modern higher school, in addition to the practical study of the material, classes develop the creative initiative of trainees, intensify their cognitive activity, and form stable professional interests. Orientation of practical training in this direction is closely related to the modeling of real production activities of future professionals, with the practical classes of the principles of problem-based learning implemented in the methodological construction. As a result, conditions are created for the reproduction of complex management situations during the lesson which a modern highly qualified specialist must effectively solve when an acute shortage of time occurs.

Of great importance is the correct organization of practical classes, and the success of the case often depends on the system of organization developed in the university, stable requirements and positive educational traditions, which are usually present in practical classes. The situation itself should have an organizational effect on trainees and make them want to work creatively. The student must always be accompanied by confidence in the successful completion of the work, supported by his/her own initiative, desire to work creatively, ingenuity and perseverance combined with good prior theoretical training [2].

The practice of higher school as a form of education is mandatory for higher education establishments and provides for the acquisition of professional skills and abilities of the established qualification level. Practical training of students is carried out with the best modern enterprises and organizations of the agricultural sector. Methods of practical training may by manifested in many forms in the process of education of agricultural students. They are distinguished by two features: by subjects; and by the nature and performance of students [4].

Skills and abilities for future professional career can be successfully acquired in laboratory-practical classes, when a specific production situation is analyzed. As noted by P.G. Luzan, "This involves the implementation of several main tasks: the use of situational tasks as a means of activating the educational and cognitive activities of students; involvement of the entire student community in productive educational work; establishment of security control over the process of acquisition of educational material "[3].

It is also important that the method of analysis of creative situations contributes to the successful formation of a set of positive personal qualities in students: the ability to establish personal contacts; ability to exchange information and form necessary points of view; ability to adapt quickly in a team working on a joint task; willingness to take responsibility for the activities of the team; ability to properly distribute and organize work; knowledge of the level of one's competence, ability to analyze and evaluate one's actions; ability to put forward and formulate ideas, propositions; readiness for risk, acceptance of nonstandard decisions; the ability to express thoughts clearly and confidently, to be succinct and intelligible; ability to 
value and productively use working time. An important advantage of this method of productive learning is its impact on the development of students' need for learning and improvement [5].

Objective. The purpose of the paper is to analyze the problem of practical training of students in higher education establishments and on the basis of the analysis to determine which factors most influence the practical training of future agricultural specialists.

Materials and methods. In the process of writing the article, professional publication materials and methods of pedagogical research were used.

Results and their discussion. Effective mastering of the content of any discipline, laid down in laboratorypractical classes, largely depends on their organization. Trainees may differ markedly from each other in the level of their intellectual development and creative thinking abilities. Intensive organizational forms of classes are designed to ensure a high level of intellectual development for all students. The process of practical training of agricultural specialists is provided by appropriate methods and practical training techniques..

Production-practical method involves their participation in the implementation of planned tasks in agricultural enterprises and organizations, as well as on farms. This contributes to the formation of organizational, entrepreneurial, economic, professional skills and abilities of future professionals.

In agricultural educational establishments of higher learning knowledge is consolidated in laboratorypractical classes, skills of practical application of knowledge are formed, control and estimation of educational achievements of trainees is carried out. The method of analysis of creative situations is very important; it contributes to the successful formation of a complex of positive personal qualities in students. The teacher focuses on the creation of such situational tasks, which are designed for active intellectual development of students, it should be borne in mind that the content of the situation should be problematic; one has to expand the educational content of the topic, which is considered in class, the adoption of the optimal solution of each situation takes place in a discussion. The main purpose of the lesson on the analysis of production situations is to consolidate, deepen knowledge, to form intellectual skills for applying knowledge in practice, the ability to describe production situations, stable cognitive needs and learning motives. It should be noted that in the imitation of relations, the didactic goal and the educational goal are closely connected: the process of forming students' professional interests is more intensive, the team unites, and participants gain experience in moral relations.

For example, in laboratory-practical classes on "Epizootology and Infectious Diseases" at State Agrarian and Engineering University in Podilia, students are offered the closest situation to production conditions, when it is necessary to make the right decision to solve a problem using their own knowledge. Several students in the group are asked to play a role in a specific production situation of a certain official, for example: chief veterinarian of an agricultural enterprise (farm, livestock facility, etc.), veterinary laboratory doctor, veterinary clinic specialist, head of the district state veterinary hospital, etc. In this case, everyone must clearly comment on their decisions under these conditions, justifying them with reference to certain guidance material. If necessary, as required by the given situational task, acting as a certain official, one is to draw up the necessary documents, for example: a cover note for pathological material to the veterinary laboratory, blood sampling to confirm the diagnosis or a plan to eliminate infectious disease, justifying the sequence of actions and specific measures. Other trainees have the opportunity to assess the correctness of the decision, discuss it in a group and even assess the competence of the acting official. At the same time, they show a lively interest in each situation, form a practical view of the production problem and, most importantly, the desire to learn to make the right and professional decision, which significantly improves the effectiveness of the educational process.

Thus, such an analysis of production situations in laboratory-practical classes provides effective formation of full activity of learners, consolidates the knowledge already acquired by them and studies new educational material, provides interdisciplinary links, there is an objective recognition and evaluation of successes by teachers and colleagues. in a group, which makes the learning process in the classroom much more meaningful and productive.

The analysis of psychological and pedagogical sources, the activities of agricultural higher education, the results of surveys of students and teachers made it possible to recognize the practical training of students as a purposeful and organized process of mastering professional knowledge, skills and abilities of future farmers.

The essence, features of practical training of agrarian students determine the psychological and pedagogical structure of this process. The structure of practical training involves the presence of the subject and object, due to the content of educational prerequisites and objectives, takes into account the laws, principles and contradictions of this process, methods, forms, types and means of practical training, which are interconnected in the system to provide the necessary result.

Thus, we have identified the following conditions for practical training: the organization of mastering the necessary cognitive skills and abilities to acquire knowledge, namely in the organization of continuous control of knowledge as a means of involvement in systematic educational activities; creation of production situations in the process of practical training; application of adequate forms of organization of employers for educational purposes in laboratory-practical classes and educational practice; ensuring the adequacy of the educational material base to the content of practical training.

Conclusions. Based on the above, we can conclude that the practical training of future agricultural specialists is influenced by the following factors: the technology of training in higher agricultural educational establishments; professional-cognitive interest and professional orientation of the student's personality, his/her value orientations; material and technical base of the educational institution; family and family traditions; professional competence of teachers; cognitive and special abilities of trainees; team learning activities; the content of practical training of the future specialist; assessment of the quality of training of agricultural specialists; forms and methods of 
practical training. The above factors will turn from possibility into reality, if the organizational and methodological support of practical training of sudents is carried out in certain pedagogical ways. On the basis of the activity approach one can substantiate the general requirements to practical training of agrarian specialists, which are concretized by the following basic provisions: maximum approximation of practical training to production; readiness to constantly deepen one's knowledge, improve practical skills; rapid adaptation to changes in both internal and external environment in professional activities; readiness to work in production conditions, to introduce advanced technologies, form the need for selfimprovement.

\section{REFERENCES}

1. Volkova N.P., Bykova V.O. Situation analysis technologies in the process of professional training of future specialists: Bulletin of Alfred Nobel University. "Pedagogy and Psychology" Series. Pedagogical sciences. Dnipro, 2017. No 2 (14). pp. 137-147.

2. Laush P.V., Kukharenko V.S., Oryshchenko S.B. Organization of practical training. K .: Urozhay, 1996. 192 p.

3. Luzan P.G. Activation of student learning / Ed. AI Dyomina. $\mathrm{K}$.: Ed. Published by Department of the Scientific Method Center of Agricultural Education, 1999. 216 p.

4. Luzan P.G. Methods and forms of education in higher agricultural school. K .: Agrarian education, 2003. 224 p.

5. Rudik Y.M, Bober V.V. Methods of conducting practical lessons on the analysis of industrial situations // Scientific

Bulletin of the National University of Life and Environmental Sciences of Ukraine. s "Pedagogy. Psychology. Philosophy"Serie. K .: Publishing Center, 2014. Issue 199. P. 2. pp. 262-268.

6. Khomenko M.P. Factors influencing the effectiveness of practical training of junior agricultural specialists // Problems of education: Scientific Methodical Center for Higher Education, 2003. Issue. 31. 360 p.

7. Yevdokimov V.I., Lutsenko V.V. Student personality as an object and subject of alternative pedagogical technologies: Theor. issues of education and upbringing. 2000. No 10. pp. $48-50$. 